\title{
A Formal Total Synthesis of Platencin
}

\author{
Kerrie A. B. Austin, Martin G. Banwell, ${ }^{*}$ and Anthony C. Willis \\ Research School of Chemistry, Institute of Advanced Studies, The Australian National \\ University, Canberra, ACT 0200, Australia
}

Vol. 10, No. 20

4465-4468

mgb@rsc.anu.edu.au

Received July 20, 2008

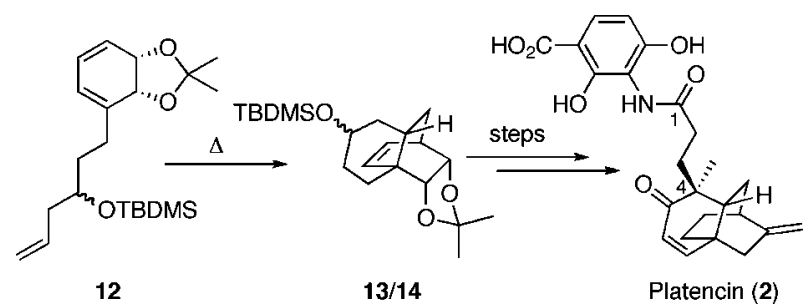

The readily available and enantiomerically pure trienes 12 undergo a thermally induced intramolecular Diels-Alder reaction to give the corresponding mixture of compounds 13 and 14. This mixture has been elaborated to an advanced intermediate associated with Nicolaou's recently reported total synthesis of the natural enantiomeric form of the antibiotic platencin (2).

In 2006, and as a part of an ongoing and global campaign to identify new generation antibiotics, a group based at Merck described the isolation and structural elucidation of the terpenoid platensimycin (1) (Figure 1). ${ }^{1}$ In the following year, the same group reported on the related natural product platencin (2). ${ }^{2}$ Both compounds, which are metabolites of strains of Streptomyces platensis, show potent antibacterial properties. Thus, platensimycin is active, with nanomolar potency $\left(\mathrm{IC}_{50}=48 \mathrm{nM}\right)$, against methicillin-resistant Staphylococcus aureus (MRSA) and acts by blocking an enzyme, FabF, involved in one of the condensation steps associated with fatty acid biosynthesis that bacteria require

(1) (a) Wang, J.; Soisson, S. M.; Young, K.; Shoop, W.; Kodali, S.; Galgoci, A.; Painter, R.; Parthasarathy, G.; Tang, Y. S.; Cummings, R.; Ha, S.; Dorso, K.; Motyl, M.; Jayasuriya, H.; Ondeyka, J.; Herath, K.; Zhang, C.; Hernandez, L.; Allocco, J.; Basilio, A.; Tormo, J. R.; Genilloud, O.; Vicente, F.; Pelaez, F.; Colwell, L.; Lee, S. H.; Michael, B.; Felcetto, T.; Gill, C.; Silver, L. L.; Hermes, J. D.; Batizal, K.; Barrett, J.; Schmatz, D.; Becker, J. W.; Cully, D.; Singh, S. B. Nature 2006, 441, 358. (b) Singh, S. B.; Jayasuriya, H.; Ondeyka, J. G.; Herath, K. B.; Zhang, C.; Zink, D. L.; Tsou, N. N.; Ball, R. G.; Basilio, A.; Genilloud, O.; Diez, M. T.; Vicente, F.; Pelaez, F.; Young, K.; Wang, J. J. Am. Chem. Soc. 2006, 128, 11916.

(2) (a) Wang, J.; Kodali, S.; Lee, S. H.; Galgoci, A.; Painter, R.; Dorso, K.; Racine, F.; Motyl, M.; Hernandez, L.; Tinney, E.; Colletti, S. L.; Herath, K.; Cummings, R.; Salazar, O.; González, I.; Basilio, A.; Vicente, F.; Genilloud, O.; Pelaez, F.; Jayasuriya, H.; Young, K.; Cully, D. F.; Singh, S. B. Proc. Natl. Acad. Sci. U.S.A. 2007, 104, 7612. (b) Jayasuriya, H.; Herath, K. B.; Zhang, C.; Zink, D. L.; Basilio, A.; Genilloud, O.; Diez, M. T.; Vicente, F.; Gonzalez, I.; Salazar, O.; Pelaez, F.; Cummings, R.; Ha, S.; Wang, J.; Singh, S. B. Angew. Chem., Int. Ed. 2007, 46, 4684. for the assembly of their cell membranes. ${ }^{1}$ Congener $\mathbf{2}$, on the other hand, is a potent and dual inhibitor of both the (bacterial) enzymes FabH and $\mathrm{FabF}^{2}$ As a consequence, it shows broad-spectrum and potent antibacterial activity against all key pathogens harboring resistance to current antibiotics. Given the common 3-amino-2,4-dihydroxybenzoic acid residues associated with compounds $\mathbf{1}$ and $\mathbf{2}$, the differing biological profiles of the two compounds must be

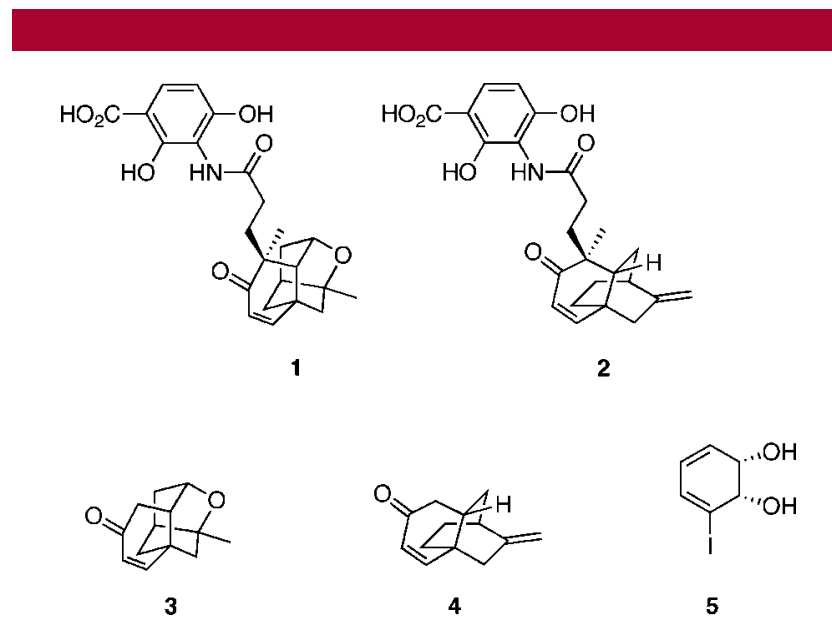

Figure 1. Compounds $\mathbf{1} \mathbf{- 5}$. 
attributed to the variations in their lipophilic core structures 3 and $\mathbf{4}$, respectively. Thus, seemingly modest changes in the nonaromatic components of these compounds can have a profound impact on antibacterial activity.

The novel structures and remarkable biological properties of platensimycin (1) and platencin (2) have attracted significant attention from the community of synthetic chemists with much of the work published to date having been focused on the former compound. ${ }^{3}$ Very recently, however, the first total syntheses of platencin (2) have been reported. ${ }^{4}$ On this basis and in view of the likely significance of the core structure $\mathbf{4}$ as a building block for the synthesis of interesting analogs, we now wish to report the enantioselective preparation of this compound from the cis-1,2dihydrocatechol $\mathbf{5}$. Compound $\mathbf{5}$ is a commercially available material that is generated in multigram quantities by the whole-cell-mediated biotransformation of iodobenzene using a genetically engineered microorganism that overexpresses the responsible enzyme, namely toluene dioxygenase (TDO)..$^{5}$

The pivotal step associated with the present route to tricyclic enone $\mathbf{4}$ uses a remarkably facile and diastereoselective intramolecular Diels-Alder (IMDA) ${ }^{6}$ reaction to establish, in a direct manner, the basic framework of the target compound. The synthesis of the substrate required for this step is shown in Scheme 1 and starts with the commercially available dienol $\mathbf{6}^{7}$ that is first converted, under standard conditions, into the corresponding and previously reported $^{8}$ tert-butyldimethylsilyl (TBDMS) ether 7. Subjection of a $\mathrm{CH}_{2} \mathrm{Cl}_{2} / \mathrm{MeOH}$ solution of this last compound and 2,6-lutidine to ozonolysis at $-78{ }^{\circ} \mathrm{C}$ and treatment of the ensuing mixture with granular sodium borohydride in $\mathrm{MeOH}$ at $0-18{ }^{\circ} \mathrm{C}$ resulted in a chromatographically separable mixture of the starting material 7 (11\% recovery), the unwanted diol $\mathbf{8}$ (46\% at $89 \%$ conversion) and the required mono-ol 9 (48\% at $89 \%$ conversion). This last compound was converted into the corresponding iodide $\mathbf{1 0}$ (75\%) using molecular iodine in the presence of triphenylphosphine and

(3) For a very recent review of synthetic studies in the area see: Tiefenbacher, K.; Mulzer, J. Angew. Chem., Int. Ed. 2008, 47, 2548.

(4) (a) Nicolaou, K. C.; Tria, G. S.; Edmonds, D. J. Angew. Chem., Int. Ed. 2008, 47, 1780. (b) Hayashida, J.; Rawal, V. H. Angew. Chem., Int. Ed. 2008, 47, 4373. (c) Tiefenbacher, K.; Mulzer, J. Angew. Chem., Int. Ed. 2008, 47, 6199. (d) Yun, S. Y.; Zheng, J.-C.; Lee, D. Angew. Chem., Int. Ed. 2008, 47, 6201. (e) Waalboer, D. C. J.; Schaapman, M. C.; van Delft, F. L.; Rutjes, F. P. J. T. Angew. Chem., Int. Ed. 2008, 47, 6576. (f) Nicolaou, K. C.; Toh, Q.-Y.; Chen, D. Y.-K. J. Am. Chem. Soc. 2008, 130, 11292.

(5) (a) Entwistle, D. A.; Hudlicky, T. Tetrahedron Lett. 1995, 36, 2591. Compound 5 can be obtained from the Aldrich Chemical Co. (Cat. No. 489492) or from Questor, Queen's University of Belfast, Northern Ireland (see: http://questor.qub.ac.uk/newsite/contact.htm). For reviews on methods for generating cis-1,2-dihydrocatechols by microbial dihydroxylation of the corresponding aromatics, as well as the synthetic applications of these metabolites, see: (b) Hudlicky, T.; Gonzalez, D.; Gibson, D. T. Aldrichim. Acta 1999, 32, 35. (c) Banwell, M. G.; Edwards, A. J.; Harfoot, G. J.; Jolliffe, K. A.; McLeod, M. D.; McRae, K. J.; Stewart, S. G.; Vögtle, M. Pure Appl. Chem. 2003, 75, 223. (d) Johnson, R. A. Org. React. 2004, 63, 117.

(6) For useful recent reviews on the IMDA reaction see: (a) Bear, B. R.; Sparks, S. M.; Shea, K. J. Angew. Chem., Int. Ed. 2001, 40, 820. (b) Takao, K.-i.; Munakata, R.; Tadano, K.-i. Chem. Rev. 2005, 105, 4779.

(7) This material was purchased from the Aldrich Chemical Co., Milwaukee, WI (Cat. No. 111589).

(8) Nugent, W. A.; Feldman, J.; Calabrese, J. C. J. Am. Chem. Soc. 1995, 117,8992 .
Scheme 1. Synthesis of Substrate 12 for the IMDA Reaction

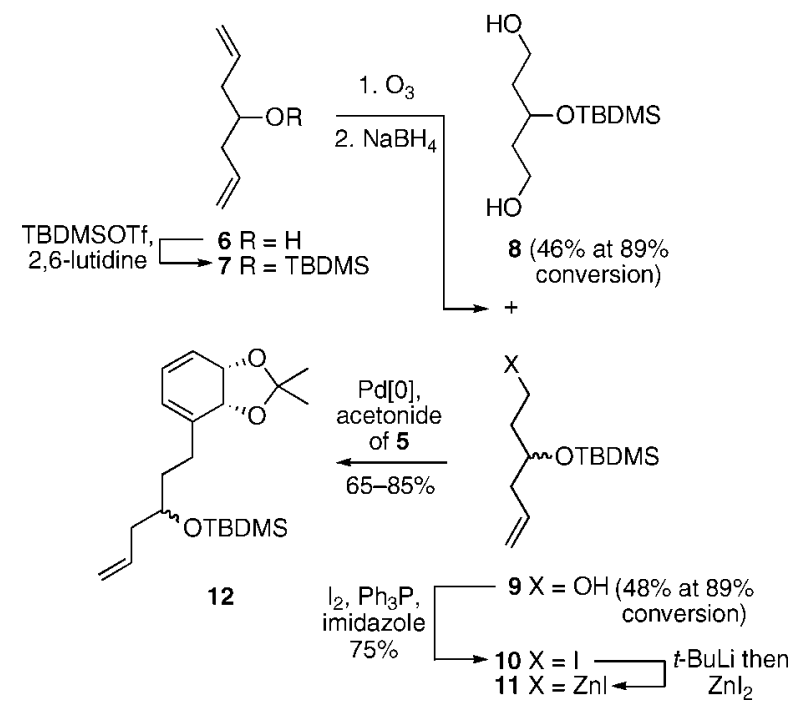

imidazole. ${ }^{9}$ Treatment of a diethyl ether solution of halide 10 with tert-butyllithium ( $t$-BuLi) then anhydrous zinc iodide (1.0 $\mathrm{M}$ solution in THF) resulted in the formation of the organozinc species $\mathbf{1 1}$ that was immediately subjected to a Negishi cross-coupling reaction ${ }^{10}$ with the known ${ }^{11}$ and readily available acetonide derivative of cis-1,2-dihydrocatechol 5. $\mathrm{Pd}\left(\mathrm{Ph}_{3} \mathrm{P}\right)_{4}$ was used as the catalyst in this reaction and by such means compound $\mathbf{1 2}$, the substrate required for the foreshadowed IMDA process, was obtained in $65-85 \%$ yield (scale dependent) and as a ca. 1:1 mixture of diastereoisomers.

The capacity of various cis-1,2-dihydrocatechols and their derivatives to engage in either inter- or intra-molecular Diels-Alder cycloaddition reactions ${ }^{12}$ prompted us to consider using the proposed IMDA approach for forming the tricyclic framework of target $\mathbf{4}$ from triene 12. However, the lack of activation of the dienophilic portion of substrate $\mathbf{1 2}$

(9) Garegg, P. J.; Johansson, R.; Ortega, C.; Samuelsson, B. J. Chem. Soc., Perkin Trans. 1 1982, 681.

(10) For a useful point-of-entry into the literature on the Negishi crosscoupling reaction see: Kürti, L.; Czakó, B. Strategic Applications of Named Reactions in Organic Synthesis; Elsevier Academic Press: Burlington MA, 2005; pp 310-311.

(11) Hudlicky, T.; Olivo, H. F.; McKibben, B. J. Am. Chem. Soc. 1994, $116,5108$.

(12) (a) Gillard, J. R.; Burnell, D. J. J. Chem Soc., Chem. Commun. 1989, 1439. (b) Banwell, M. G.; Dupuche, J. R. Chem. Commun. 1996, 869. (c) Banwell, M. G.; Dupuche; J. R.; Gable, R. W. Aust. J. Chem. 1996, 49, 639. (d) Banwell, M. G.; Hockless, D. C. R.; Holman, J. W.; Longmore, R. W.; McRae, K. J.; Pham, H. T. T. Synlett 1999, 1491. (e) Banwell, M. G.; McRae, K. J.; Willis, A. C. J. Chem. Soc, Perkin Trans. 1 2001, 2194. (f) Banwell, M. G.; Edwards, A. J.; Harfoot, G. J.; Jolliffe, K. A. J. Chem. Soc., Perkin Trans. 1 2002, 2439. (g) Banwell, M. G.; Chun, C.; Edwards, A. J.; Vögtle, M. M. Aust. J. Chem. 2003, 56, 861. (h) Banwell, M. G.; Darmos, P.; Hockless, D. C. R. Aust. J. Chem. 2004, 57, 41. (i) Banwell, M. G.; McLeod, M. D.; Riches, A. G. Aust. J. Chem. 2004, 57, 53. (j) Banwell, M. G.; Edwards, A. J.; Harfoot, G. J.; Jolliffe, K. A. Tetrahedron 2004, 60, 535. (k) Banwell, M. G.; Edwards, A. J.; McLeod, M. D.; Stewart, S. G. Aust. J. Chem. 2004, 57, 641. (1) Banwell, M. G.; Harfoot, G. J. Aust. J. Chem. 2004, 57, 895. (m) Banwell, M. G.; Austin, K. A. B.; Willis, A. C. Tetrahedron 2007, 63, 6388. (n) Reekie, T. A.; Austin, K. A. B.; Banwell, M. G.; Willis, A. C. Aust. J. Chem. 2008, 61, 94. 
meant that there was concern about whether or not an endoselective cycloaddition reaction would be observed and whether the activation energy required to initiate such a process might be prohibitively high. In the event (Scheme 2) it was pleasing to observe that by simply heating a toluene

Scheme 2. Outcome of the IMDA Reactions of Triene 12
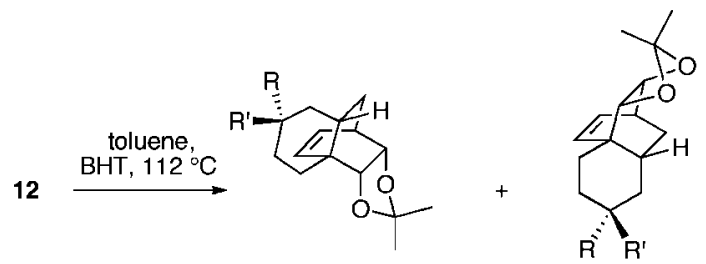

$13 \mathrm{R}=\mathrm{H}, \mathrm{R}^{\prime}=$ OTBDMS (44\%) $15 \mathrm{R}=\mathrm{H}, \mathrm{R}^{\prime}=$ OTBDMS $(4 \%)$ $14 \mathrm{R}=$ OTBDMS, $\mathrm{R}^{\prime}=\mathrm{H}(45 \%) \quad 16 \mathrm{R}=$ OTBDMS, $\mathrm{R}^{\prime}=\mathrm{H}(4 \%)$

solution of compound $\mathbf{1 2}$ at reflux for $16 \mathrm{~h}$ a smooth cycloaddition reaction took place that led to a chromatographically separable mixture of adducts 13 (44\%), 14 (45\%), $15(4 \%)$, and $16(4 \%)$. The structures of these products follow from single crystal X-ray analyses of each of them or the associated alcohols. ${ }^{13}$ In all instances these products have been formed via an endo-transition state and the generation of the latter pair of adducts has involved the addition of the dienophile to the sterically more crowded face of the diene, namely that face of the $4 \pi$-system bearing the $\mathrm{C}-\mathrm{O}$ bonds of the acetonide ring. ${ }^{12 \mathrm{j}-1}$

Diels-Alder adducts $\mathbf{1 3}$ and $\mathbf{1 4}$ represent the ones embodying the required enantiomeric form of the tricyclic framework of target 4. Accordingly this pair of diastereoisomers was combined and carried forward in the synthesis. Specifically, and as shown in Scheme 3, the mixture of compounds $\mathbf{1 3}$ and $\mathbf{1 4}$ was treated with tetra$n$-butylammonium fluoride (TBAF) at $18{ }^{\circ} \mathrm{C}$ and the resulting crystalline alcohols hydrogenated at $1 \mathrm{~atm}$ in the presence of $10 \%$ palladium on carbon. The ensuing saturated systems were then subjected to $O$-benzoylation under standard conditions. Derivatization in this manner provided the ester 17, as a mixture of epimers, in $91 \%$ combined yield over the three steps. Hydrolysis of the acetonide residue within these epimers could be accomplished using acid-activated DOWEX-50 resin in aqueous $\mathrm{MeOH}$ at reflux for $72 \mathrm{~h} .{ }^{14}$ However, even under such forcing conditions complete conversion into the corresponding diol 18 (97\% combined yield at $63 \%$ conversion) could not be achieved. Selective monooxidation of compound $\mathbf{1 8}$ could be effected using the sterically demanding $N$-oxoammonium salt derived from 4-acetamido-TEMPO and $p$-toluenesulfonic acid monohydrate $\left(p-\mathrm{TsOH} \cdot \mathrm{H}_{2} \mathrm{O}\right)$ and in this manner the corresponding acyloin was obtained (as a mixture of epimers). As a prelude to its removal, the free hydroxyl group within this oxidation product was benzoylated to afford diester 19 (77\% yield over 2 steps). Treatment of compound 19 with $\mathrm{SmI}_{2}$ in $\mathrm{THF} / \mathrm{MeOH}$ at $-78{ }^{\circ} \mathrm{C}$ resulted in smooth reduction to the corresponding monobenzoate $\mathbf{2 0}$ (quantitative yield). Subjection of compound $\mathbf{2 0}$ to standard Wittig methylenation conditions resulted in the formation of the corresponding olefin 21 (84\% yield) and the ester residue within the latter compound was then saponified, using potassium carbonate in $\mathrm{MeOH}$. This gave the corresponding unsaturated alcohol, oxidation of which (using 2-iodoxybenzoic acid (IBX) ${ }^{15}$ in DMSO for $16 \mathrm{~h}$ ) provided the ketone $22\left(\mathrm{mp} 57-59{ }^{\circ} \mathrm{C}\right.$ ) in quantitative yield. The structure of compound $\mathbf{2 2}$ was confirmed by a single-crystal X-ray analysis. ${ }^{13}$

Completion of the synthesis of the target compound 4 required the dehydrogenation of precursor 22. While a variety of reagents could be used to accomplish this conversion it has, thus far, been impossible to avoid coproduction of isomer 23. Under the best conditions identified to date, which involve a protocol defined by Lalic and Corey in their synthesis of platensimycin, ${ }^{3}$ a

Scheme 3. Elaboration of Diels-Alder Adducts 13 and 14 to Target 4

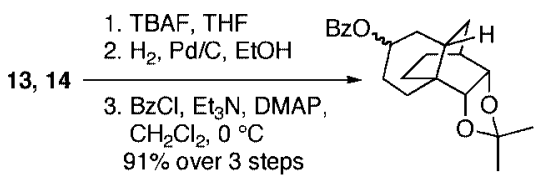

17

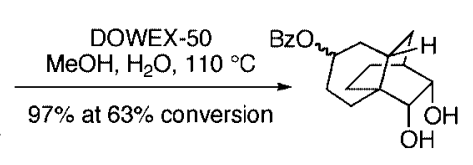

18

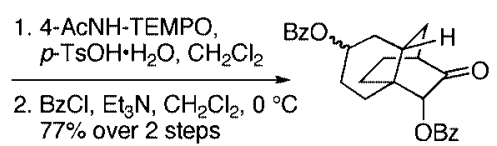

$77 \%$ over 2 steps

19

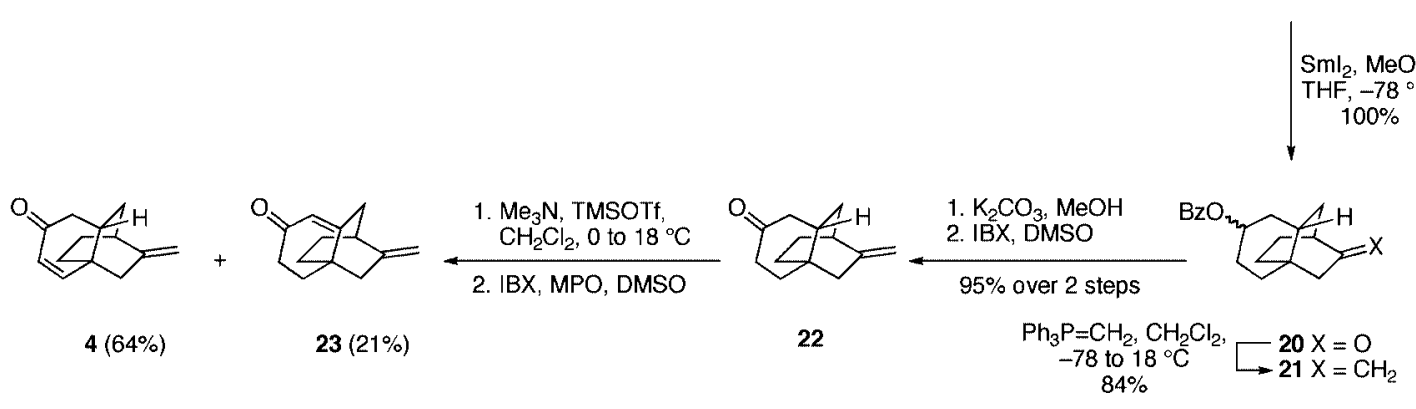


solution of substrate 22 in $\mathrm{CH}_{2} \mathrm{Cl}_{2}$ was cooled to $0{ }^{\circ} \mathrm{C}$ then treated with trimethylamine and trimethylsilyl triflate (TMSOTf). A DMSO solution of the resulting mixture of silyl enol ethers was treated, at $18{ }^{\circ} \mathrm{C}$, with IBX and 4-methoxypyridine- $N$-oxide (MPO). ${ }^{16}$ In this way a chromatographically separable mixture of compounds 4 (64\%) and $23(21 \%)$ was obtained. The spectral data derived from each of these compounds were in full accord with the assigned structures. Furthermore, the ${ }^{1} \mathrm{H}$ and ${ }^{13} \mathrm{C}$ NMR data obtained on enone $\mathbf{4}$ matched those reported by Nicolaou et al. ${ }^{4 a}$

The acquisition of enone 4 by the means described here constitutes a formal total synthesis of platencin because of the recent reports ${ }^{4}$ from the groups of Nicolaou and Rawal describing the conversion of compound $\mathbf{4}$ into the target $\mathbf{2}$. This conversion is achieved using protocols analogous to those employed for transforming the related enone $\mathbf{3}$ into

(13) For X-ray crystallographic data see the Supporting Information.

(14) The rather vigorous hydrolysis conditions used here are frequently required $^{12 \mathrm{~m}, \mathrm{n}}$ to cleave acetonides annulated in this manner to the bicyclo[2.2.2]octanyl framework.

(15) Frigerio, M.; Santagostino, M.; Sputore, S. J. Org. Chem. 1999, $64,4537$.

(16) (a) Nicolaou, K. C.; Gray, D. L. F.; Montagnon, T.; Harrison, S. T. Angew. Chem., Int. Ed. 2002, 41, 996. (b) Nicolaou, K. C.; Zhong, Y.-L.; Baran, P. S. J. Am. Chem. Soc. 2000, 122, 7596. platensimycin (1). The synthesis of enone $\mathbf{4}$ described here has been accomplished in 17 steps and $9.5 \%$ overall yield.

An interesting feature of the present approach to platencin is that the IMDA reaction of triene $\mathbf{1 2}$ not only produces the anti-addition products $\mathbf{1 3}$ and $\mathbf{1 4}$ but their counterparts $\mathbf{1 5}$ and $\mathbf{1 6}$ arising from the equivalent syn-addition processes. In principle, this latter pair of compounds could be elaborated, using protocols essentially identical to those detailed in Scheme 3, to ent-4. Work directed toward such ends as well as toward exploiting the present route in the production of platencin analogs is currently underway in our laboratories.

Acknowledgment. We thank the Institute of Advanced Studies and the Australian Research Council for generous financial support.

Supporting Information Available: Preparation and characterization of selected compounds; CIFs, single-crystal $\mathrm{X}$-ray data and atomic displacement ellipsoid plots for compounds 13-16 (or their associated alcohols) and $\mathbf{2 2}$ (CCDC nos. 687717-687721, respectively); and ${ }^{1} \mathrm{H}$ or ${ }^{13} \mathrm{C}$ NMR spectra of compounds 4, 7-10, and 12-23 (and/or their associated alcohols). This material is available free of charge via the Internet at http://pubs.acs.org.

OL801647H 